CURRENT RESEARCH JOURNAL OF HISTORY 2(5): 31-36, May 2021

DOI: https://doi.org/10.37547/history-crjh-02-05-10

ISSN 2767-472X

(C)2021 Master Journals

Crossref doi gil Google

Accepted 25th May, 2021 \& Published 30th May, 2021

\title{
STUDYING THE HISTORY OF THE DEVELOPMENT OF THE HEALTHCARE SYSTEM IN UZBEKISTAN DURING THE YEARS OF INDEPENDENCE
}

\author{
Mukhabbat Madirimovna Makhmudova \\ Department Of Propaedeutics Of Internal Medicine Tashkent Medical Academy Urgench Branch \\ Urgench, Uzbekistan
}

\section{ABSTRACT}

The article briefly highlights the history of the study of the health problem by Uzbek scientists in a certain period of time. The works of the authors are divided into groups based on their quality, nature and focus. Monographic and dissertation research is especially highlighted. Used methods of chronological and comparative analysis, particular attention is paid to the study of orientalists of Uzbekistan and publications of foreign authors. It is recognized that as a result of the implementation of the results of dissertation research by individual authors, there is an optimization of the structure of health care authorities and a decrease in the level of disease in the population.

Over the years of independence, a health care reform program has been implemented. Much has been done to improve its quality and culture of timeliness and efficiency. A network of urgent emergency care, rural medical outpatient clinics and city polyclinics, multidisciplinary specialized clinics, scientific centers has been created. Medical care for women and children of the country is provided at the level of world standards, personnel training is carried out in 14 medical universities and one pharmaceutical institute, in 85 medical colleges. Advanced training and retraining of medical personnel is carried out in universities and an advanced training institute.

At present, it is one of the most important branches of the country's national economy. As a result of socioeconomic and medical measures in Uzbekistan, medical care has become universal and publicly available, such dangerous diseases as cholera, plague, smallpox, parasitic typhus, trachoma have been eliminated, and the incidence of many others has been reduced. Over the past 10 years, the incidence of the population with such socially dangerous ailments as congenital defects by $32.4 \%$, infectious diseases by $40 \%$, the incidence of the upper respiratory tract has decreased by 4.2 times. The incidence of diphtheria, paratyphoid fever, poliomyelitis, malaria has been completely eradicated [1].

The health care system employs about 650 thousand people (this is almost 10 percent of the able-bodied population of the republic), including more than 84 thousand doctors and 500 thousand paramedical workers. An extensive network of medical institutions in Uzbekistan is capable of providing the necessary medical and preventive care to the entire population.

KEYWORDS: - Uzbekistan, health care history, monograph, dissertation, doctors, rape, scientists, etc. 
CURRENT RESEARCH JOURNAL OF HISTORY 2(5): 31-36, May 2021

DOI: https://doi.org/10.37547/history-crjh-02-05-10

ISSN 2767-472X

(C)2021 Master Journals

Crossref doi 8 Google

Accepted 25th May, 2021 \& Published 30th May, 2021

\section{INTRODUCTION}

In 1991, Uzbekistan gained its independence. By this time, a centralized state health care system had been formed in the republic. During the years of independence, it has become one of the most important sectors of the economy. The history of the development of the healthcare system in the republic has been in the focus of research scientists, doctors and public figures. As a result, the number of scientific papers devoted to the problem is growing. Over time, they multiply again and research is conducted in the spirit of the times.

Research methods: Periodicity and comparative analysis methods were used.

\section{Purpose and mission}

From the point of view of historiography, it is possible to analyze the existing research work by dividing it into several parts. The first group can include the works of authors who were directly involved in the process and based on generalized documents based on their own knowledge. Among the authoritative studies are those who once served as Minister of Health - Academician Sh.I. Karimov, professors F.G. Nazirov, A.I. Ikramov, A.V. Olimov, Deputy Minister D.A. Asadov's work stands [2.160;2-5;65-74549-555]. The published works of the above-mentioned authors differ in quality and degree. Some of them not only collected interesting information, but also managed to write meaningful scientific works based on in-depth analysis, study and generalization of them.

The second group includes scientific works of coauthors on the problems of the health care system of the republic. In particular, in 1998, academician Sh.I. Karimov has published a monograph entitled "Health in Uzbekistan: Problems and Prospects". Scientists of the Tashkent Institute of Postgraduate Medical
Education A.Yu. Ibrohimov, D.A. Asadov and P.R. Menlikulov wrote a good article on the main directions of health care reform in the country [3.55-57]. Professor D.A. For the first time in the country, Asadov and his co-authors tried to show a cost-effective approach to health care reform, the peculiarities and prospects of its development [4.57].

The third group includes a number of scientific papers devoted to the analysis of the activities carried out in the health care system. In 2013, the collection "Primary health care in Uzbekistan: achievements and challenges" was published [5.127]. It summarizes the results of the reform of primary health care in the country over the past 10-15 years. The book is based on the projects of the Ministry of Health, the World Health Organization (WHO) and the World Bank (WB) "Health-1-2".

Valuable analytical information and suggestions can be found in the following publications: "Improving the training of primary care physicians in Uzbekistan" [6.14], "Assessment of telemedicine development in the Republic of Uzbekistan", "Strategy and development of ehealth" [7], "Reforming the financing and management of the primary health care system" [8.84], "Uzbekistan: Health System Analysis", "Health System Financing" [9].

In 2015, Professor M. Mahmudov wrote a book entitled "Doctors Training Center in Khorezm." [10.152] Journalist L. Sailkhonova published an article on the training of doctors at the Urgench branch of the Tashkent Medical Academy [11]. Researcher D.G. Tashmuhammedova analyzed the process of training highly qualified scientific and medical personnel in the country on the basis of the Higher Attestation Commission (HAC) [12.122-124]. In 2017, the Russian Medical Journal published an article entitled "Development of the health care system in Uzbekistan" [13]. 
CURRENT RESEARCH JOURNAL OF HISTORY 2(5): 31-36, May 2021

DOI: https://doi.org/10.37547/history-crjh-02-05-10

ISSN 2767-472X

(C)2021 Master Journals

\section{Crossref dof 80 Google}

Accepted 25th May, 2021 \& Published 30th May, 2021

The fourth group includes fundamental works of historians, economists, medical scientists on the general history of Uzbekistan, the history of medicine and health, monographs. In this regard, M.M. Mahmudov and B.H. Umurzakov's monograph "Health in Uzbekistan (historical records)" has a special place [14.104]. Because the book was published on the eve of independence, the authors were forced to cover limited details of recent history.

In January 2000, Karshi State University lecturer G.E. Muminova PhD on "Medicine and health in Kashkadarya and Surkhandarya regions in 19461990: problems and consequences" [15.28] and in December 2018 defended his doctoral dissertation on "History of the health care system in Uzbekistan in the Soviet era (1917-1991)" [16.54]. Although the author did not attempt to shed light on the years of independence, taking into account the periodic boundary, he did focus on some problems in the process of substantiating the relevance of the topic and in the concluding part.

In November 2019, Samarkand-based researcher S.A. Jumanov defended his doctoral dissertation on "History of the development of the main directions of the health system in Uzbekistan (1991-2015) [17.50]. It provides a partial analysis of the overall work done during the years of independence to develop the industry and address the shortcomings. However, the author tries to substantiate the misconception that drugs are stored in warehouses of extremely dangerous and toxic chemicals [17.13]. Medicines created for medical needs are becoming more and more commercial today and sometimes harm patients instead of benefiting them.

The problems of reducing the morbidity and mortality of pregnant women and pregnant women in the ecologically unfavorable situation in the South Aral Sea region are reflected in the doctoral dissertation of O.A. Otaniyozova. In the course of research, the author identified the prevalence of diseases such as anemia, tonsillitis, gastritis, hepatitis, renal rheumatism among women and girls [18.7]

Researcher A.K. Hamroev's doctoral dissertation on "Improvement of organizational work against drug-resistant tuberculosis in the Aral Sea region" was defended in 2015. The research is based on the activities carried out in the Republic of Karakalpakstan in 1991-2011, the results of research conducted with the participation of medical staff of Nukus, Chimbay, Karauzak and Takhtakor districts and the author to study the prevalence of tuberculosis in 2003-2011.

In the course of the research, the author came to the conclusion that in Karakalpakstan, some work is being done in the organization of $\mathrm{TB}$ diagnosis and treatment. The number of TB facilities and their beds was 1.8 times higher than needed. Therefore, the dissertation provides practical recommendations on optimizing the number of these institutions and their places [19.56].

Special mention should be made of the contribution of orientalists to the coverage of the life and work of Central Asian scientists. In particular, thanks to many years of work of the corresponding member of the Academy of Sciences of Uzbekistan U.I. Karimov, the great Abu Rayhan Beruni's work "Kitab as-Saydona" ("Pharmacognesia") was studied and published. Orientalists A. Irisov [20.81] and S.U. Karimova [21. 10-20; 302; 126] as a result of his scientific research, the pages of the rich heritage and life of Abu Ali ibn Sina were illuminated. Academician D. Yunusova [22.140-145;535], Doctors of History B.A. Abduhalimov [23.33-39], M. Hasanov [24.126;368], Associate Professor H. Xikmatullaev's [25.81;80] the invaluable contribution of Central Asian scientists to the development of science, including medicine, in 
CURRENT RESEARCH JOURNAL OF HISTORY 2(5): 31-36, May 2021

DOI: https://doi.org/10.37547/history-crjh-02-05-10

ISSN 2767-472X

(C)2021 Master Journals

Crossref doi 81 Google

Accepted 25th May, 2021 \& Published 30th May, 2021

return for their tireless research and fruitful work has been widely covered.

The fifth group includes the works of foreign scientists and researchers. Ignoring the content and essence of their scientific work, it was considered a fabrication based on fake research. But in time, foreign scientists began to obtain new information about the former Soviet republics and tried to accurately cover the real situation based on them [26.237]. At the same time, some of them do not recognize the changes in the development of the world and the health system in Central Asia. For example, in 2008, the American Michael Tenner wrote a large article entitled "Comparative Analysis of the Health System in Different Countries" in an attempt to highlight their strengths and weaknesses [27]. Unfortunately, the article does not contain a single word in the context of "there is a state called Uzbekistan, which also carries out public health work".

Among foreign scholars, economist I.M. Sheiman's monograph on "Health System Management and Financing Reform" is noteworthy. Although the large-scale study deals with the activities carried out in the healthcare system of the Russian Federation, the author's conclusions and recommendations are valuable for Uzbek specialists.

Information published in periodicals and Internet sites also plays an important role in covering the history of healthcare in Uzbekistan and monitoring the process of radical reforms in the sector. They help in timely observation, analysis and objective coverage of events and happenings.

\section{Results AND Discussion}

A brief analysis of the available sources and literature shows that the state of public health in Uzbekistan, its achievements and shortcomings, as well as the selfless work of its staff are not fully covered in the pages of historical works. Hence, since the problem has not found its own comprehensive in-depth analysis, it needs to be studied more broadly from the point of view of historiography.

\section{Conclusion}

The research focuses on the theoretical development of strategies and concepts of health care reform in the years of independence, strengthening its funding, management and logistics, strengthening key links in primary care - emergency care and sanitary-epidemiological control, formation of a system of rural medical centers and family clinics, further improvement of medical services for mothers and children, training and retraining of specialists, it is necessary to pay attention to such topical issues as the development of science, the expansion of international relations, the role of public organizations in the provision of health care to the needy.

\section{REFERENCES}

1. Karimov I.A. Results of 2011 and priority areas of social and economic development of the republic in 2012. Report at a meeting of the Cabinet of Ministers // "Truth of the East", 2012, February 19.

2. Karimov, Sh.I. and others. Problems and Prospects of Health Care in Uzbekistan // R.G. Muxamedyarova , V.E. Chernyavskiy, R.K. Yansupov, B.D. Durmanov (na angl. i russ. yaz.). - Moscow: Izd-vo "World of Economics and Law",1998. - P. 160; Nazirov, F.G. Public health and health care management in the Republic of Uzbekistan: state and prospects" // Medical Journal Uzbekistan (MJU).- 2003. - № 5. - P. 2-5; Ikramov, A.I. i dr. The global trend of intensifying the use of bed 
CURRENT RESEARCH JOURNAL OF HISTORY 2(5): 31-36, May 2021

DOI: https://doi.org/10.37547/history-crjh-02-05-10

ISSN 2767-472X

(C)2021 Master Journals

Crossref doi 81 Google

Accepted 25th May, 2021 \& Published 30th May, 2021

resources // MJU. - 2009. - № 6; Alimov, A.V. Reforming primary health care services in Uzbekistan: successes and development prospects achieved // www.minzdrav.uz; Asadov, D.A. Costeffectiveness analysis of health systems // MJU. - 2003. - № 6. - P. 65-74; Ego je: Health in Uzbekistan // National Encyclopedia of Uzbekistan. - Tashkent:. 8. - Toshkent:, 2004. - P. 549-553.

3. 3. Ibragimov, A.Yu. and etc. The main directions of health care reform in the Republic of Uzbekistan // D.A. Asadov, P.R. Menlikulov// "Problems of "social hygiene" and health care organizations" (Moscow:). -2012. - № 1. - P. 55-57.

4. Asadov, D.A. and etc. Healthcare system of the Republic of Uzbekistan: main trends and development prospects // T.Yu. Aripov, Sh.B. Irgashev. - Tashkent: Center for Economic Research, 2011. - P. 57.

5. Development of Primary Health Care in Uzbekistan: Achievements and Challenges". Analytical overview // D. Mavlyanova, R.Muxamedyarova, S Abduraximova, F. Fuzaylov, E. Tsoy. Tashkent: Uzbekistan, 2013. - P.127.

6. Improvement of doctors of primary memory in Uzbekistan. World Bank Memorandum // K. Fazy'lov, Benjamin Mills. -Tashkent:, 1999. - P. 14.

7. Strategy for the creation and development of "E-health" in the Republic of Uzbekistan for the implementation period 2013-2020 // M. Baimukhammedov. - Tashkent, October 7, 2015 Slides".

8. The health sector and the reform of the system 'financing and management of primary health care. - Tashkent: USAID
SShA, 2005. - P. 84.

9. Financing the health system: A road to universal health coverage. World health report. - Jeneva, World Health Organization,2010.

10. Mahmudov, M. Doctor training center in Khorezm. - Urgench: TTAUF, 2015. - P. 152.

11. Sailxanova, L. Forge of doctors of Khorezm // "Truth of the East",-2015. 20 November.- № 225.

12. Tashmuxammedova, D.G. Problems of the training of highly qualified scientific medical personnel in Uzbekistan // MJU. - 2007. - № 3. - P. 122-124.

13. Development of the healthcare system in Uzbekistan // Russian medical journal ("RMJ"), 2017. -№ 6 // www.mij.ru.

14. Maxmudov, M.M., Umurzakov B.X. Healthcare of Uzbekistan. -Tashkent: Ibn Sina, 1991. - P. 104.

15. Muminova, G.E. Medicine and health care of Uzbekistan: problems and consequences (1946-1990) (based on materials from the southern regions of Uzbekistan): Author's abstract of the dissertation of Doctor of Philosophy (Phd) - Tashkent 2000. - P.28.

16. Muminova, G.E. History of the healthcare system in Uzbekistan (1917-1991) . Tashkent:, 2018. - P. 54.

17. Djumanov S.A. History of the development of the main directions of the health care system in Uzbekistan (19912015). Author's abstract of the dissertation of Doctor of Philosophy (Phd). - Toshkent, 2019. - P. 50,13.

18. Ataniyazova, A.A. Reproductive function of women in the region of the Aral Sea 
CURRENT RESEARCH JOURNAL OF HISTORY 2(5): 31-36, May 2021

DOI: https://doi.org/10.37547/history-crjh-02-05-10

ISSN 2767-472X

(C)2021 Master Journals

\section{Crossref dof Google}

Accepted 25 $5^{\text {th }}$ May, 2021 \& Published 30th May, 2021

ecological crisis. Author's abstract of the dissertation of Doctor of Philosophy (Phd). - Moscow:, 1996. - P. 7.

19. Xamraev, A.K. Improvement of the organization of anti-tuberculosis memory taking into account the prevalence drugresistant forms of tuberculosis in the Aral Sea region (by the example of the Republic of Karakalpakstan). Author's abstract of the dissertation of Doctor of Philosophy (Phd). - Tashkent:, 2015. P. 56.

20. Irisov, A. Hakim ibn Sina: life and work. Tashkent: O'zbekiston, 1982. - P. 81.

21. Karimova, S.U. Ibn Sino // National Encyclopedia of Uzbekistan. 4 - vol. -Tashkent, 2002. - P. 10-20; Karimova, S.U: Collection of eastern's manuscripts of the Academy of Sciences of the Republic of Uzbekistan. Medicine. (Kh. Khikmatullaev).- Tashkent: Science, 2000. - P. 302; Karimova, S.U. Navoi period medicine. (M. Hasanov). Toshkent: Ibn Sina, 1991. - P. 126.

22. Yusupova, D.Yu. Science, education, medicine // In the collection "Amir Temur in world history". -- Paris, 1996. P. 140-145; Collection of oriental's manuscripts of the Academy of Sciences of Uzbekistan. History // Comp. D. Yusupova, R. Djalilova. -Tashkent: Science, 1998. - P. 535.

23. Abduhalimov, B.A. Bayt ul-Hikma and the Scientific Activities of Central Asian Scholars in Baghdad: -- Tashkent:, 2001; Abduhalimov, B.A: When you're created "Bayt al-xikma" // "Shark mash'ali". Toshkent:, 2000. - № P. 1-2. 63-68; Abduhalimov, B.A: Central Asian Studies in Baghdad (1X-X1 vv.) // History of Uzbekitan - Tashkent, 1999. - № 4. -

\section{P.33-39.}

24. Hasanov, M.H. Faxruddin Ali Safiy. "Rashahot". - Toshkent: Ibn Sino, 2003; Hasanov, M.H.: Navoi period medicine. (In collaboration with S.U. Karimova.). Tashkent: Ibn Sino, 1991. - 126 b.; Medicinal gems // Collector and compiler -- M. Hasanov. - Tashkent: Ibn Sino, 1990. - P. 368.

25. Hikmatullaev, H. Oriental medicine. -Tashkent: Ibn Sino, 1991. - P. 81; Same author: Abu Ali ibn Sina. Mysterious medicine. - Tashkent: Ibn Sino, 2015. - P. 80.

26. Prinz A. Etnomedizin-Gesenichte der Vedizin. Wissenchaften vom heilkundlichen Denken und handlen desmenschen - Wien. Kin, Wochenscher, 1991; Martin Miller. Freud and the Bolsheviks: Psychoanalysis in ImperialRussia and the Soviet Union. New Haven: Yale University Press, 1998. - P.237; Borowitz M., O Dougherty, S.Wickham, C. et al. Conceptual Foundations for Central Asian Republic Health Reform Model, Technical Report ofthe Zdrav Reform Program. - Almaty: Abt Associates. 1999; Ilkhamov A. and Jakubowski E. Health Care Systems inTransition: Kazakistan. - Copenhagen: European Observatory on Health Care Systems; Martin McKee, Judith Healyand Jane Falkingham, Health care in Central Asia. European Observatory on Health Care Systems; Bukingham Phlladelphia. 2002.

27. Michael Tanner.The Grass Is Not Always Greener: A Look at National Health Care Systems Around the World // Policy Analysis. № 613. March 18, 2008 // www.inlibertv.ru. 